\title{
Did The Introduction of Carbon Tax In Australia Affect Housing Affordability?
}

\author{
Xin Janet $\mathrm{Ge}$ \\ School of Built Environment, University of Technology Sydney, PO Box 123 Broadway, NSW 2007 \\ Australia \\ xinjanet.ge@uts.edu.au
}

Keywords: Carbon tax, Construction Activity, Housing Affordability, Government Policy, Australia.

\begin{abstract}
The Australian carbon pricing schemes (carbon tax) was introduced and became effective on 01 July 2012. The introduction of the carbon tax immediately raises the electricity costs to a number of industries such as manufacturing and construction. Households are also affected as a result of pricing passing through from the affected industries. The carbon tax addresses greenhouse emissions and energy reductions in Australia. However, the carbon tax may consist of economic risks in Australian housing market, in particular the impact of housing affordability.
\end{abstract}

\section{Introduction}

An average output of 20.58 tonnes of greenhouse gas (GHG) emissions per person per year in Australia are largely produced by generating electricity, petroleum refining and gas processing by using coal [1]. A number of greenhouse emissions reduction schemes have been introduced in Australia to help mitigate the effects of climate change and improve the global environment since the signing of the Kyoto Protocol in December 1997. A carbon pricing schemes (also called 'carbon tax') is one of the schemes introduced under the Clean Energy Acts from 01 July 2012. The aim of scheme is to reduce of GHG emissions in Australia by 5 per cent below 2000 level by 2020 and 80 per cent below 2000 level by 2050 [2]. The biggest polluters such as electricity generators and industrial sectors in Australia are required to pay their pollution under the carbon pricing mechanism. However, the scheme does not apply to road transport and agriculture.

The initial price of a permit for one tonne of carbon was fixed at \$23 for the 2012-2013 financial year with unlimited permits being available from the Government. The price will be increased to $\$ 24.15$ for 2014-2015 and $\$ 25.40$ for 2015-2016, where market rate will be applied from 01 July 2015 [2]. Businesses such as manufacturing and constructions are heavily affected by the sharp rise of energy costs since the introduction of the carbon tax. On the other hand, households have also affected as they have to pay the higher electricity bills as results of pricing passing through by the energy companies. There are debates on whether the carbon tax should be abolished as the introduction of carbon tax has distorted the Australian economy.

The official rates were cut 225 basis points since November 2011 in Australia to address the growing uncertainty about global and domestic economic conditions. Fig. 1 depicts the economic and property market performances in Australia for the period of March 2002 to June 2013.The per cent change of gross domestic product (GDP) has been decreased and the unemployment rate has edged high at around 6 per cent. At the same time the prices of both project homes and the established houses of the Australian eight capital cities have been consistently increased. This indicates that many Australian households are less affordable to purchase their homes or service their mortgage loans. The introduction of carbon tax has added extra expenses on their bills which have made them even unaffordable.

The economic effects of greenhouse gas emission measures and implications of a carbon tax have been widely investigated over decades $[3,4,5,6,7,8,9 \& 10]$. The advantages and disadvantages of a carbon tax were identified and discussed by Pearce [10]. Winkler and Marquard [3] elaborated the reasons of a carbon tax in South Africa and concluded that a carbon tax is one of the most effective mitigation options. Concerning the relocations of greenhouse gas emission from a carbon tax 
implemented countries to the countries that have no policy, Hoel [9] studied a group of countries and suggested a carbon tax should not be differentiated across sectors in the economy. Consumer response in Sweden due to changes in environmental policy was analyzed by Brannlund and Nordstrom [6]. The results of their simulation concluded that household living in densely populated areas carries a larger share of the tax burden. Parry, et al.[13] employed analytical and numerical models to assess the welfare effects of a revenue-neutral carbon tax and carbon emissions permits. They recommended that an appropriately scaled carbon tax supports welfare-improving when environmental damages are positive.

Fewer researches have focused the impact of carbon tax to the housing affordability. This research studies on whether the introduction of carbon tax in Australia affects housing affordability. Though there is not direct linkage between the carbon tax and the housing affordability, the introduction of carbon tax schemes have in effect added pressure on housing supply and increased housing prices. The study is timely and significant in the context of contemporary growing concerns on housing affordability and addressing global warm around the world. The research also adds to the body of knowledge on side effects of policy implications which are a research gap remaining for further study.

Next section will discuss the effect of the introduction of carbon tax schemes on business sectors and households, following by discussing the housing affordability in Australia. The relationship between the introduction of carbon tax and the housing affordability will then be demonstrated through a statistics method using data collected from the Australian Bureau of Statistics (ABS) and Reserve Bank of Australia (RBA). Finally, policy implications will be discussed and concluded.

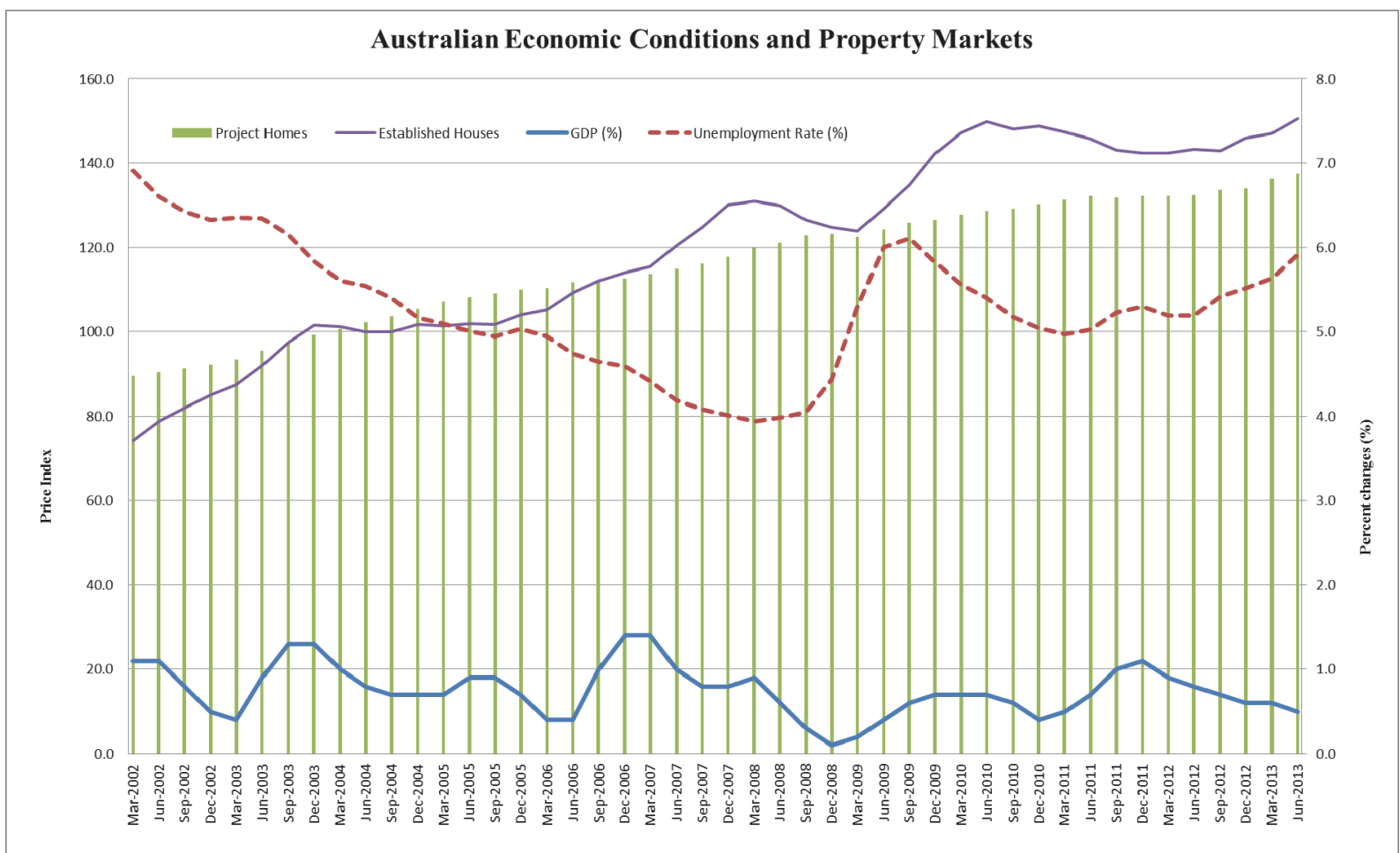

Fig. 1: Australian Economic Indicators and Property Markets (Source: ABS)

\section{The Impacts of Australian Carbon Pricing Schemes}

Australian government [11] reported a 7.7 per cent decline in greenhouse gas emissions in the National Electricity Market (NEM) as resulted in its first year of operation the carbon tax; where electricity generation have reduced to a 10 year low and the coal generation has also down 11 per cent from 2008-2009. However, Price and Harris [12] argued that carbon tax scheme contributes little to the reduction in carbon dioxide (CO2) emissions. The decline in greenhouse gas emissions was largely explained by factors unrelated to the carbon tax. These factors included a continuation of a 
trend of declining electricity demand that began three years earlier; hydro generators shifting production from the year before the carbon price to the year after the carbon price to earn higher returns; and shutting down of a significant amount of brown coal generation in Victoria immediately before the commencement of the tax due to a mine flood.

Raising the costs of production in the affected industry and higher price of consumption goods are the two identified effects of carbon tax [13]. A survey conducted by the Australian Industry Group [14] pointed out that around half of all businesses experienced an increase in their energy and other costs immediately after the carbon tax was introduced on 01 July 2012. The survey indicates that an average energy costs was 14.5 per cent increased among the business sectors, where manufacturing and construction businesses suffered the most, increased of 14.5 and 14.8 per cent respectively. More than 52 per cent construction industry business reported that the construction costs have risen immediately from as a direct result of the carbon tax. In response to the higher costs, around half of the businesses increase their selling prices and passing pricing through to the end users. Among construction industry businesses, 44 per cent had planned to increase their selling prices [14]. One of the Australia's biggest building material companies [15] claimed the introduced carbon tax will increase the cost of building products and hurt housing affordability, as well as create job losses.

On the other hand, since the introduction of the carbon tax on 01 July 2012, electricity and gas prices for households have been increased by more than 18 per cent per year, which is a single largest price increase since the early 1980s [14]. Fig. 2 depicts the price increases for household electricity and gas supplies. The figure shows that national average electricity prices for households increased by 30 per cent between 2000 and 2005, and then by another 50 per cent between 2005 and 2010. The price rise in the third quarter 2012 takes electricity pricing 40 per cent above 2010 levers, and 168 per cent higher than in 2000. Households have to sacrifice their food or their family activities to meet the additional energy bills.

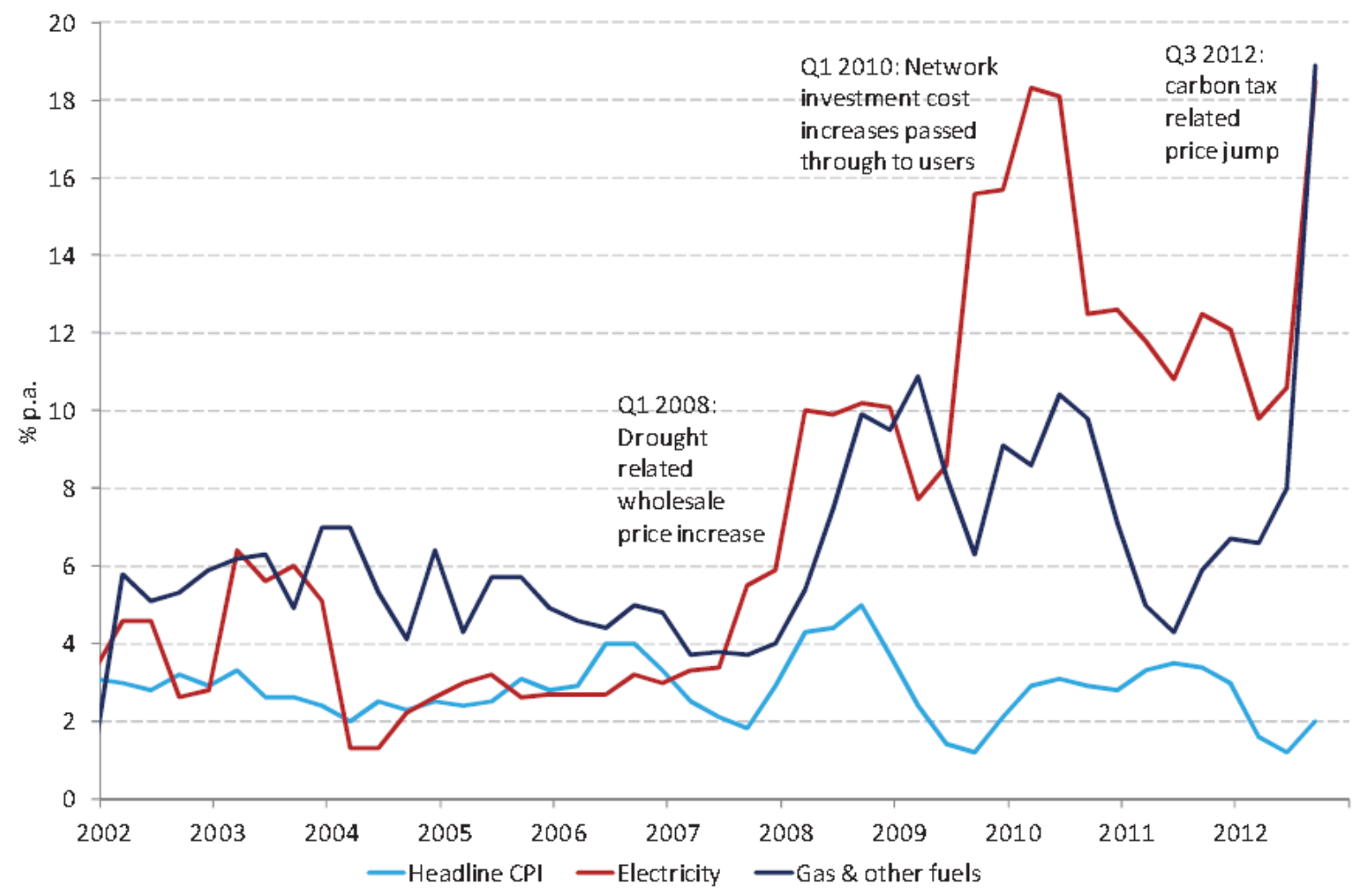

Source: ABS, Consumer Price Index (CPI), September 2012.

Fig. 2: Price Increases For Household Electricity and Gas Supplies [14] 
House prices have a tremendous increased in Australia during the last decade. The weighted average 8 capital cities house prices of established detached houses and project homes have risen by 102.6 and 53.6 per cent respectively from March 2002 to June 2013, according to the Australian Bureau of Statistics' price index (Refer to Fig. 1). Sydney has the most expensive housing in Australia, with the median house price at AUD 673,681 (approximately USD 620,353), about 26.2 per cent above the weighted average [16]. However, household incomes have increased far less than house prices, approximately 13 per cent increase, from $\$ 7,638.2$ in 2002-03 to \$8,630.4 per week in 2011-12 [17]. Cox and Pavletich [18] use the Median Multiple (i.e., Median house price/Median household income) to assess housing affordability, where Median Multiple of 5.1 and above indicates 'severely unaffordable', Median Multiple between 4.1 and 5.0 indicates 'seriously unaffordable'. In their 2013 $9^{\text {th }}$ Annual Demographia International Housing Affordability Survey, Australia had a Median multiple of 6.5 and ranks third as most unaffordable major market among the seven developed nations such as Canada, Hong Kong, Ireland, New Zealand, the United Kingdom and the United States. Sydney's Median Multiple was 8.3 is the least affordable market in Australia.

Australian affordability crisis is a product of persistent increasing of dwelling prices. Both booming demand and constraints on the supply of dwellings, especially a shortage of land in the capital cities and skill shortages within the housing industry are responsible to the risen prices [19]. Yates [20] pointed out the affordability crisis is response to increasing of number of households as results of population growth and decreasing household size; increasing income and finance availability and location preferences such as households tend to select dwellings that close to infrastructure and coast. On supply side, increasing cost of land and time taken for release of new land are important attributes of the least affordability [20]. Government zoning and other land use controls play the dominant role in making housing expensive [21].

Housing affordability attracts a major policy concern [22]. This is because the affordability problems could affect social and economic sustainability [20,18]. Movements in house prices can affect households' spending through a direct wealth effect and collateral effect [23], as well as impact on the profitability of residential construction [24]. The increase of house prices encourages household consumption that contributes to economic growth $[25,26]$. On the other hand, rapid increases in house prices are associated with the overheating investment [27] and driven an unsustainable expansion in demand. In addition, households may reduce consumption to meet their increased mortgage payments which will hold back the economic development $[20,26]$. Housing affordability issues may create social problems such as disparities in wealth [20] and impact on the regional demographic structure [26].

\section{Analysis of Effects of Carbon Tax on Housing Affordability}

Housing affordability is determined by the housing prices and household income. Given that the household incomes are relatively stable, changes of housing prices are the main attributes to the affordability. Housing prices are affected by the demand for and supply of the available houses in the markets. Thus, any of the factors that impact on the demand for and supply of housing will cause changes of housing prices, thus affordability.

Carbon tax can be effect on the affordability in the number of ways which is shown in Fig. 3. Firstly, the introduction of carbon tax increases electricity and gas expenses immediately thus the construction costs. The higher construction costs will reduce profit margins that depress the construction activities. Housing supply will be decreased in the long run that pushes up house prices. If the additional construction costs pass through, house prices increase that deducts housing affordability. Secondly, disposable income of households will reduce as additional expenses on the electricity and gas bills. Housing affordability decreases since less money will be available by households to save for home deposit or serve interest costs on mortgage.

Two tests are developed to analyse whether the introduction of carbon tax has an impact on housing affordability. Since the introduction of the carbon tax increases the costs of construction [14], the first step is to test how construction costs are related to the house prices, and the relationship 
between housing affordability and construction costs using regression analysis. The second test uses a case study to demonstrate how the introduction of carbon tax that reduces the households' debt-service ability.

House Prices/Affordability and Construction Costs. Construction costs consist of building material and labor costs. Increases of any of the building products and wages will increase construction costs. Usually, construction costs are estimated and quoted before demolition and developments. The costs of construction are constantly adjusted based on the changing of various cost factors and market conditions. Carbon tax is one of the additional costs which are suggested pushing up construction costs [14]. If the construction costs are strongly linked to the house prices at the same period, construction pricing passing through can be asserted.

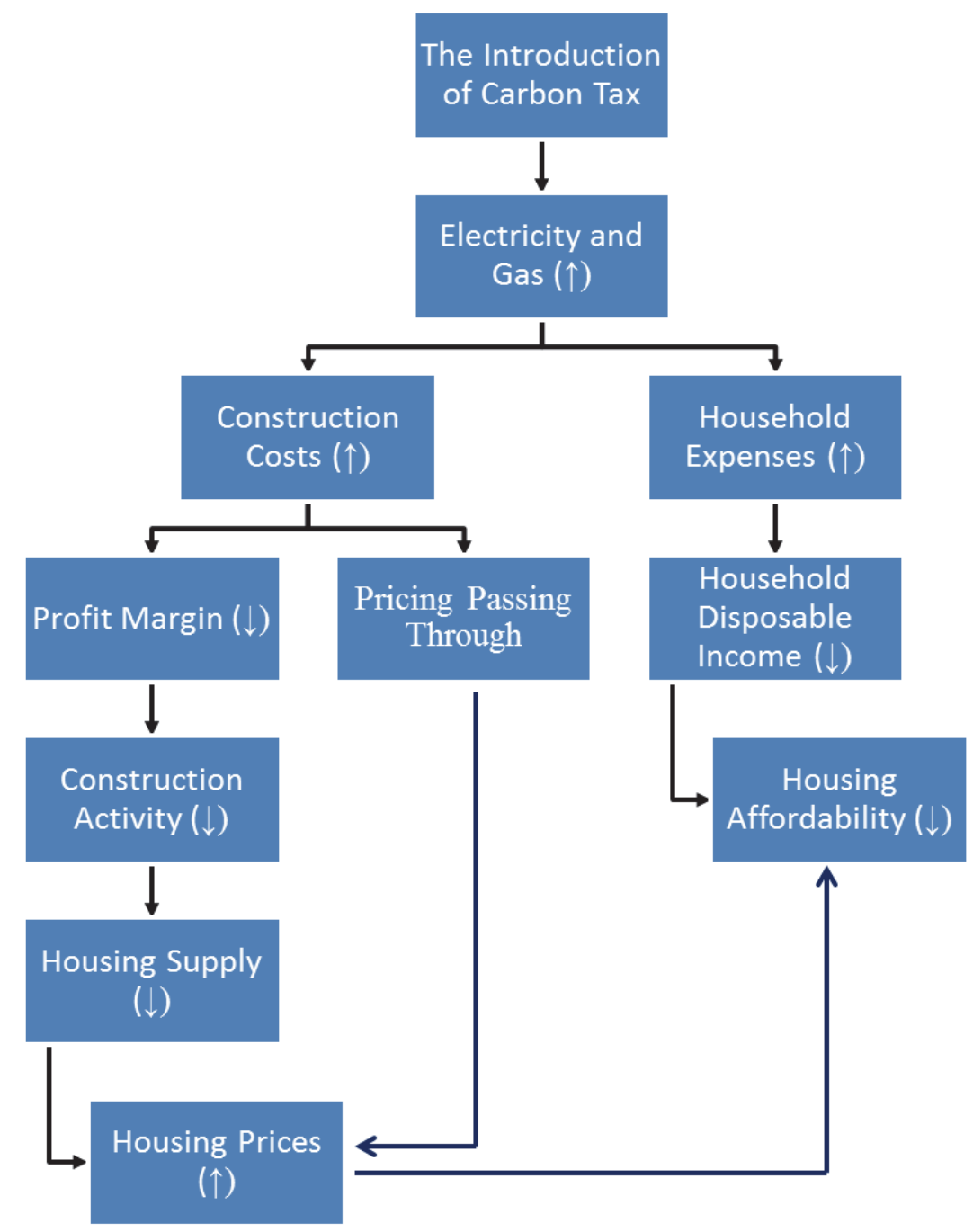

Fig. 3: The Relationship between Carbon Tax and Housing Affordability

The relationships between house prices and construction costs are presented as:

$$
N P H I=\alpha+\beta C C I
$$

Where NHPI is the house price index for project homes of eight capital cities in Australia. There are house price index for Project Homes and Established Houses in Australia [28]. Project homes indicate the dwellings are newly developed and the established houses are the existing houses are traded. House price index of project homes is selected in this study. The producer price indexes is 
used as a proxy of construction cost $(C C I)$, which includes attributes such as products of concrete, cement, steel, plumbing, etc. and electrical equipment and installation [28]. Total of 106 quarterly datasets from March 1987 to June 2013 (2003-04 = 100) for both NHPI and CCI were collected from Australian Bureau of Statistics [28] for testing. A positive correlation between NHPI and CCI are expected, i.e., the higher the construction costs and the higher the house prices for the developments of new houses.

Similarly, the introduciton of carbon tax has effects on housing afforadability can be tested by the following relationship:

$$
H A I=a+b B P I .
$$

Where $H A I$ is the housing affordability index that is measured by Median house price to Median household income, i.e.,

$$
H A I=\frac{\text { Median House Price }}{\text { Median Household Income }}
$$

The higher the house prices, the higher the housing affordability index, the the greater the unaffordable for housing. The annual median house prices of eight Australian capital cities are available from the Real Estate Institute of Australia (REIA). The annual gross household disposable income per capita collected from Australian Bureau of Statistics [28] is used as a proxy of median household income.

$B P I$ indicates cost indices on building activities which include labour, material and related construction costs. The annual datasets were derived by average up the building indices from the eight capital cities in Australia provided by Rawlingsons [29]. Total 22 annual datasets were collected for the period from June 1990 to June 2012. It is expected that the cost of builidng activities is positively linked with the housing affordability index. Table 1 presents the data information that include data sources, data period, measurements and basic statistical analysis used for the study.

\begin{tabular}{|c|c|c|c|c|c|c|}
\hline Variables & NHPI & CCI & MHP & DHP & HAI & BPI \\
\hline Definition & $\begin{array}{l}\text { House Price Index } \\
\text { for New Houses }\end{array}$ & $\begin{array}{l}\text { Construction Price } \\
\text { Index }\end{array}$ & $\begin{array}{c}\text { Median House } \\
\text { Prices }\end{array}$ & $\begin{array}{l}\text { Disposable } \\
\text { Household } \\
\text { Income }\end{array}$ & $\begin{array}{l}\text { Affordability } \\
\text { Index }\end{array}$ & $\begin{array}{l}\text { Building } \\
\text { Price Index }\end{array}$ \\
\hline Period & \multicolumn{2}{|c|}{ Mar 1987 - Jun 2013} & \multicolumn{4}{|c|}{ Jun 1990 - Jun 2002} \\
\hline Sample & \multicolumn{2}{|c|}{106 quarterly data } & \multicolumn{4}{|c|}{22 Yearly data } \\
\hline Measurement & \multicolumn{2}{|c|}{ Index } & \multicolumn{2}{|c|}{ Dollars } & \multicolumn{2}{|c|}{ Index } \\
\hline Mean & 89.2 & 95.02 & 254,335 & 25,914 & 9.223 & 139.46 \\
\hline Std Deviation & 26.47 & 18.66 & 128,746 & 8,453 & 1.817 & 37.96 \\
\hline Data Sources & $\begin{array}{l}\text { ABS, Price Index of } \\
\text { Project Homes; } \\
\text { Weighted Average of } \\
8 \text { Capital Citie }\end{array}$ & $\begin{array}{l}\text { ABS, Price Index of } \\
\text { Input to the House } \\
\text { construction } \\
\text { industry, Weighted } \\
\text { Average of } 6 \text { Capital } \\
\text { Cities }\end{array}$ & $\begin{array}{c}\text { REIA, ABS, } \\
\text { Median House } \\
\text { Prices, Average } \\
\text { of } 8 \text { Capital } \\
\text { Cities }\end{array}$ & \begin{tabular}{|c|} 
ABS, Gross \\
household \\
disposable \\
income per capita
\end{tabular} & $\begin{array}{l}\text { Derived from } \\
\text { Median House } \\
\text { Prices / Median } \\
\text { Household } \\
\text { Income }\end{array}$ & $\begin{array}{l}\text { Rawlingsons } \\
2012 \text { 'Price } \\
\text { Indices' p.3 }\end{array}$ \\
\hline
\end{tabular}

Table 1: Data Information

Two linear regression models were derived using the SPSS software and the results are shown in Table 2. The robust of the models are measured by the $R$ square, F-test and model significance, as well as $t$-test for the independent variables. In the Model 1, price index of project homes (NHPI) is the dependent variable and the producer price index $(C C I)$ is the independent variable. All regression results indicate the model is statistical significance and fits well. Fig. 4 displays that the original and the estimated price index of project homes walks along and coincided together in the later years. The model explained 96.9 per cent of the variables in the regression that indicates a very strong positive connection between the house prices and construction costs. A one per cent increase in the 
construction costs will induce 1.396 per cent increase in the house price of new developments given that other variables remain unchanged.

The housing affordability index is the dependent variable and the building price index is the independent variable tested in the SPSS statistical software. The model 2 also exhibits a statistical significance and explained 88.9 percent of the variables in the regression. The mean square error $(M S E)$ is 0.36 that demonstrates the model is robust. The costs of construction were positively related with housing affordability index. For every point increase in the building cost index is associated with a 0.045 increase in housing affordability index, holding other variables constant. This implies that households are less affordable by increasing of construction costs.

Table 2: Statistical Results

\begin{tabular}{|l|r|r|}
\hline Regression Results & \multicolumn{1}{|c|}{ Model 1 } & \multicolumn{1}{c|}{ Model 2 } \\
\hline Dependent & \multicolumn{1}{|c|}{ NHPI } & \multicolumn{1}{c|}{ HAI } \\
\hline Constant & -43.442 & 2.927 \\
\hline \multicolumn{1}{|c|}{ t-test (Sig.) } & $-18.207(.000)$ & $5.692(.000)$ \\
\hline CCI t-test (Sig.) & 1.396 & \\
\hline BPI t-test (Sig.) & & 0.045 \\
\hline R Square & 0.969 & $0.000)$ \\
\hline F-test & 3208.256 & 160.424 \\
\hline Model Sig. & 0.000 & 0.000 \\
\hline
\end{tabular}

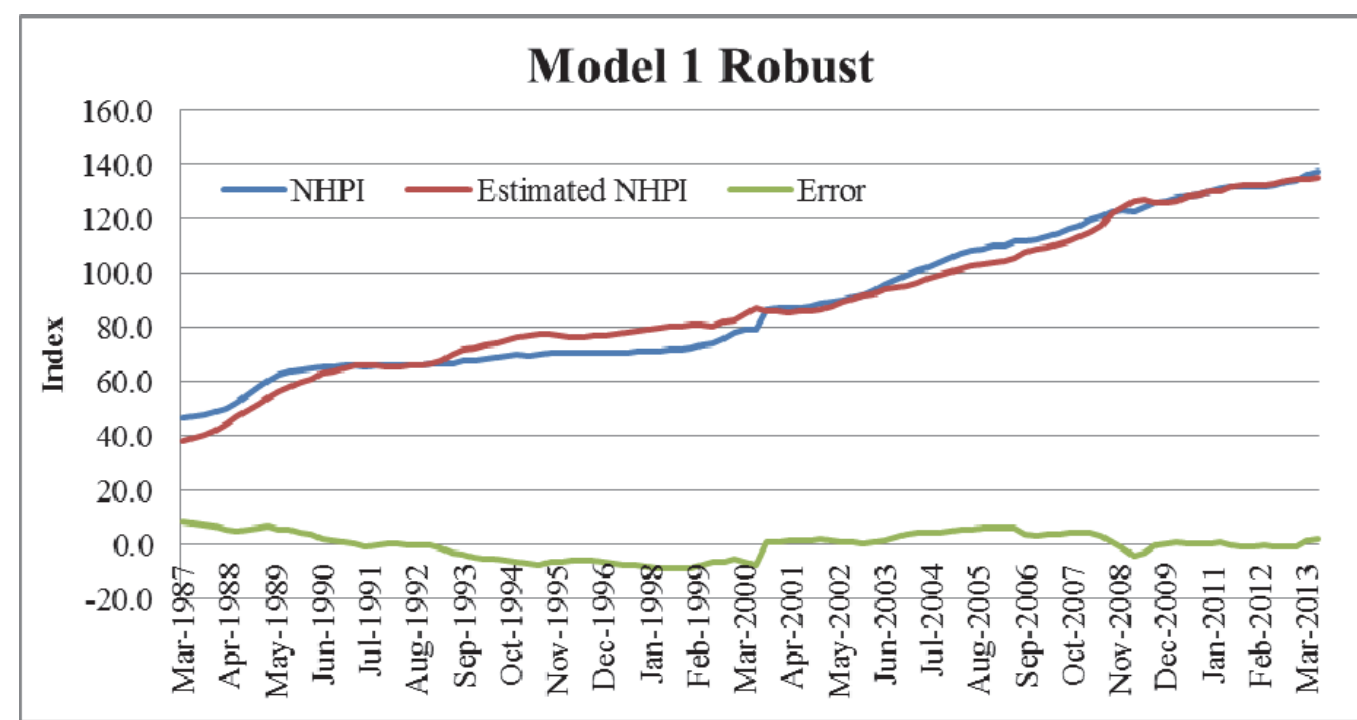

Fig. 4: The Original and Estimated House Price Index of Project Homes in Model 1

2011 Australian census data is employed to analyse the effects of carbon tax that reduces household expenditure. In Australia, there were more than 8.69 million occupied private dwellings in which 34.9 per cent dwellings (approximately 2.7 million) were owned with mortgage and 23.7 per cent dwellings (approximately 2.3 million) were rented. Nationally, the monthly median mortgage repayment was $\$ 1,800$ (approximately $\$ 450$ per week) and weekly rent was $\$ 285$. According to the 2011 census, 23.7 per cent of households had a weekly household income of less than $\$ 600$ and 11.2 per cent of households had a weekly income of more than $\$ 3,000$ [30]. Approximately 90 per cent of the households have less than 30 per cent of household income to pay their mortgage or rent.

The ABS Household Expenditure Survey (HES)[31] suggested that electricity, gas, heating oil and wood accounted for $\$ 32$ per week of household expenditure in 2009-10. Since carbon tax was introduced, the electricity and gas costs increased by 40 per cent above 2010 levers [14], i.e., $\$ 45$ per week of household expenditure. 
The analysis consists of comparing median household mortgage or rent payments with the weekly money available for mortgage or rent before and after the carbon tax. The estimating procedure involves:

a. investigating household income levels and money available for mortgage or rent payments;

b. researching median mortgage or rent per household;

c. estimating average weekly costs of electricity and gas payments before and after the carbon tax;

d. calculating the money available for mortgage or rent payments by subtracting the additional costs of electricity and gas payments; and

e. comparing the difference between median mortgage or rent with the money available for mortgage or rent before and after the carbon tax.

Assume that households pay rent when their weekly incomes are less than $\$ 1,500$ and pay mortgage when their weekly incomes greater than $\$ 1,500$. For easy comparison, the median weekly mortgage and rent, as well as electricity and gas costs remain the same for all income categories. The estimating results are shown in the Table 3.

Table 3: Estimating Results of Money Available for Mortgage or Rent per Week

\begin{tabular}{|c|c|c|c|c|c|c|c|c|c|c|c|c|}
\hline Household weekly income [22] & $\$ 600$ & $\$ 950$ & $\$$ & 1,200 & $\$$ & 1,500 & $\$ 1,800$ & & 2,100 & & 2,500 & $\$ 3,000$ \\
\hline Proportion of the income for housing (2011) [22] & $30 \%$ & $30 \%$ & & $30 \%$ & & $30 \%$ & $30 \%$ & & $30 \%$ & & $30 \%$ & $30 \%$ \\
\hline Money available for mortgage or rent at 2011 & $\$ 180$ & $\$ 285$ & $\$$ & 360 & $\$$ & 450 & 540 & $\$$ & 630 & $\$$ & 750 & 900 \\
\hline Median rent per week [22] & $\$ 285$ & $\$ 285$ & $\$$ & 285 & & & & & & & & \\
\hline Median mortgage per week [22] & & & & & $\$$ & 450 & $\$ \quad 450$ & $\$$ & 450 & $\$$ & 450 & 450 \\
\hline Affordability before carbon tax & No & Yes & \multicolumn{2}{|c|}{ Yes } & \multicolumn{2}{|c|}{ Yes } & Yes & \multicolumn{2}{|r|}{ Yes } & \multicolumn{2}{|r|}{ Yes } & Yes \\
\hline 2009-10 electricity \& gas costs [23] & 32 & 32 & $\$$ & 32 & $\$$ & 32 & 32 & $\$$ & 32 & $\$$ & 32 & 32 \\
\hline Increased electricity \& gas (2012-13) [6] & $40 \%$ & $40 \%$ & & $40 \%$ & & $40 \%$ & $40 \%$ & & $40 \%$ & & $40 \%$ & $40 \%$ \\
\hline 2012-13 electricity \& gas costs & 45 & 45 & $\$$ & 45 & $\$$ & 45 & 45 & $\$$ & 45 & $\$$ & 45 & 45 \\
\hline Additional costs of electricity \& gas & 13 & 13 & $\$$ & 13 & $\$$ & 13 & 13 & $\$$ & 13 & $\$$ & 13 & 13 \\
\hline Money available for mortgage or rent after carbon tax & $\$ 167$ & $\$ 272$ & $\Phi$ & 347 & $\$$ & 437 & $\$ 527$ & $\$$ & 617 & $\$$ & 737 & 887 \\
\hline Proportion of the income for housing (2012-13) & $27.9 \%$ & $28.7 \%$ & & $28.9 \%$ & & $29.1 \%$ & $29.3 \%$ & & $29.4 \%$ & & $29.5 \%$ & $29.6 \%$ \\
\hline Affordability after carbon tax & No & No & & No & & No & Yes & & Yes & & Yes & Yes \\
\hline
\end{tabular}

Before the carbon tax, households are not affordable to rent or buy houses when their weekly income less than $\$ 950$. The households have to rely on government assistance for their housing. The households who have weekly income levels between $\$ 950$ and $\$ 1,500$ are affordable to access rental markets, while households who have weekly income above $\$ 1,500$ are affordable to access homeownership by paying mortgage. Since the introduction of carbon tax, the costs of electricity and gas have increased by 40 per cent [14]. This implies that an additional $\$ 13$ has to use for paying the increased electricity and gas bills each week by households. Given other expenses remain unchanged; the money available for mortgage or rent is reduced after the introduction of carbon tax. As displayed in the Table 3, households who have weekly income between $\$ 950$ to $\$ 1,500$ were original affordable to pay their mortgage or rent are now unaffordable after the carbon tax was introduced. The household weekly incomes that are greater than $\$ 1,500$ have less impact from the carbon tax introduced. The higher the household incomes, the less the impacts from the carbon tax. Obviously, the low-to-moderate income households suffer the most though there are some subsidy programs available from governments.

\section{Discussion, Summary and Conclusions}

A carbon tax is one of the effective measures to reduce greenhouse gas emission [10]. Some positive impacts from a carbon tax can be identified such as an encouragement to the use of substitute materials and the development of technologies to reduce the costs over time [32]. Nevertheless, the introduction of carbon tax in Australia in 2012 created a significant cost impact to the building and construction industry. An indirect consequence of the carbon tax not only adds economic burdens to the building and construction industry, but also deteriorates housing affordability.

This research has analyzed how the introduction of carbon tax effects on house prices thus housing affordability. Empirical and simulation scenario analysis have been employed to conduct the tests. 
The study results coincide with the earlier research [10] that consumers who will bear some portion of the tax as industries try to minimize compliance costs. The findings are also in line with other similar studies [6] where carbon tax pricing passing through to households.

The reduction of greenhouse gas emission is a long-term issue that needs a lasting effort to be mitigated substantially [3]. An introduction of carbon tax should be considered among the range of instruments involving interactions between environmental, economic and political, social and technological processes [3]. Any policies will have positive and negative two sides. Careful analysis of the carbon tax impacts on each of the stakeholders will enhance long-term success of the policy introduced. Timing of introducing the carbon tax and the global and local economic conditions are also worthwhile to assess before the policy implementation. It is evidenced that Australian economic activities were slowed down and business confidents were reduced as result of the carbon tax. Remove the carbon tax thus is claimed as one of the Coalition's positions to help increase affordable housing supply in Australia[33].

This analysis has found that the carbon tax has strong impacts on the low-to-moderate income households in Australia. One is the direct impact on the increased cost of energy used and some indirect cost factors, such as higher costs for housing and their costs of transportation. The combined costs factors have made the low-to-moderate income households are less affordable to housing. Some incentive programs such as free basic electricity [3] are recommended to assist the group households to overcome the difficulties of maintaining their housing. Other the measures

\section{References}

[1] S. Lauder: Australians The 'World's Worst Polluters, ABC News (Australian Broadcasting Corporation (2009). Retrieved on 10 Sep 2013 at http://www.abc.net.au/news/2009-09-11.

[2] Commonwealth of Australia: Securing a Clean Energy Future - The Australian Government's Climate Change Plan in Summary, Australian Government (2011).

[3] H. Winkler and A. Marquard: Analysis of the Economic Implications of a Carbon Tax, Journal of Energy in Southern Africa, Vol 22/1 (2011), pp. 55-67.

[4] R. Sathre and L. Gustavsson: Effects of Energy and Carbon Taxes on Building Material Competitiveness, Energy and Buildings, Vol. 39 (2007), pp. 488-494.

[6] R. Brannlund and J. Nordstrom: Carbon Tax Simulations Using a Household Demand Model, European Economic Review, Vol. 48 (2004), pp. 211-233.

[7] R. Green: Carbon Tax or Carbon Permits: The Impact on Generators' Risks, The Energy Journal, Vol. 29/3 (2008), pp.67-89.

[8] C. Bohringer and T.F. Furtherford: Carbon Taxes with Exemptions in an Open Economy: A General Equilibrium Analysis of the German Tax Initiative, Journal of Environmental Economics and Management, Vol. 32 (1997), pp. 189-203.

[9] M. Hoel: Should a Carbon Tax be Differentiated Across Sectors? Journal of Public Economics, Vol. 59 (1996), pp. 17-32.

[10] D. Pearce: The Role of Carbon Taxes in Adjusting to Global Warming, The Economic Journal, Vol. 101/407 (1991), pp. 938-948.

[11] Commonwealth of Australia: Australian National Greenhouse Accounts - Quarterly Update of Australia's National Greenhouse Gas Inventory December quarter 2012, Australian Government (2013).

[12] Frontier Economics: Post Hoc Ergo Propter Hoc, Client Brief, 7 August 2013. 
[13] I.W.H. Parry, R.C. Williams III and L.H. Goulder: When Can Carbon Abatement Policies Increase Welfare? The Fundamental Role of Distorted Factor Markets. Journal of Environmental Economics and Management, Vol. 37 (1999), pp.52-84.

[14] Australian Industry Group: Ai Group Survey: Business Pricing Responses to Australia's Carbon Tax, The First Six Months (2013).

[15] J. Bayley: 2013 Election Housing and Homelessness Report Card, Analysis, The Community Housing Coalition of WA, 05 September 2013.

[16] L.C. Delmendo: Housing Market Slowly Recovering in Australia, Financial Review, Global Property Guide, 18 July 13. Retrieved at http://www.globalpropertyguide.com/Pacific/Australia.

[17] Australian Bureau of Statistics: Household Income and Income Distribution, 6523.0.

[18] W. Cox and H. Pavletich: the $20139^{\text {th }}$ Annual Demographia International Housing Affordability Survey, Demographia and Performance Urban Planning, 2013.

[19] A. Beer, B. Kearins and H. Pieters: Housing Affordability and Planning in Australia: The Challenge of Policy Under Neo-liberalism, Housing Studies, Vol. 22/1 (2007), pp. 11-24.

[20] J. Yates, V. Milligan, M. Berry, Tl Burke, M. Gabriel, P. Phibbs, S Pinnegar and B. Randolph: Housing Affordability: a $21^{\text {st }}$ Century Problem, National Research Venture 3: Housing Affordability for Lower Income Australians, Final Report, Australian Housing and Urban Research Institute, National Housing Conference, 2007.

[21] E.L. Glaeser and J. Gyourko: The Impact of Building Restrictions on Housing Affordability, FRB New York, Economic Policy Review, Vol. 9 (2003), pp. 21-39.

[22] J.Q. Quigley and S. Raphael: Is Housing Unaffordable? Why Isn't It More Affordable? Journal of Economic Perspectives, Vol. 18/1 (2004), pp. 191-214.

[23] K. Flood and S. Morin: House Prices and Consumer Spending, Bank of Canada Review, Summer (2008), pp. 31-44.

[24] N. Girouard and S. Blöndal: House Prices and Economic Activity, Organisation for Economic Cooperation and Development, Economics Department Working Paper No. 279, OECD Publishing (2001). Doi:10.1787/061034430132.

[25] M. Berry: Housing Affordability and the Economy: A Review of Macroeconomic Impacts and Policy Issues, National Research Venture 3: Housing Affordability for Lower Income Australians, Research Paper 4, Australian Housing and Urban Research Institute, RMIT-NATSEM Research institute, 2006.

[26] Z.M. Wang, J.H. Han and B. Lim: The impacts of housing affordability on social and economic sustainability in Beijing, Australasian Journal of Construction Economics and Building, Conference Series, Vol. 12/1 (2012), pp. 47-55.

[27] C. Leung: Macroeconomics and Housing: A Review of the Literature, Journal of Housing Economics, Vol. 13 (2004), pp. 249-267.

[28] Australian Buruea of Statistics: information on http://www.abs.gov.au

[29] Rawlinsons Australian Construction Hangbook 2012: Building Indices, 30 edition (2012), Rawlinson Publishing, p. 3.

[30] Australian Buruea of Statistics: 2011 Census: information on http://www.censusdata.abs.gov.au.

[31] Australian Buruea of Statistics: ABS Household Expenditure Survey (HES), information on http://www.abs.gov.au/AUSSTATS/abs@.nsf/DetailsPage/6503.02009-10. 
[32] Centre for International Economics: Effects of a Carbon Price on the Building and Construction Industry (2011), Information on www.TheCIE.com.au.

[33] P. Wen: Carbon tax will hurt housing affordability: Brickworks, Business Day, The Sydney Morning Herald, 24 March 2011. 